\title{
Lectin histochemical analysis of uterine natural killer cells in normal, hydatidiform molar and invasive molar pregnancy
}

\author{
TING ZHONG ${ }^{1,2^{*}}$ XINGXING XIE $^{1 *}$, TENG ZONG $^{1}$, XIAOCHUN YU ${ }^{1}$, YAN LING $^{3}$ and HAIBIN KUANG ${ }^{1}$ \\ ${ }^{1}$ Jiangxi Provincial Key Laboratory of Reproductive Physiology and Pathology, Department of Physiology, \\ School of Medicine, Nanchang University, Nanchang, Jiangxi 330006; ${ }^{2}$ Department of Reproductive Medicine, \\ First Affiliated Hospital of Gannan Medical University, Ganzhou, Jiangxi 341000; ${ }^{3}$ Department of Obstetrics \\ and Gynecology, Jiangxi Province People's Hospital, Nanchang, Jiangxi 330006, P.R. China
}

Received January 2, 2017; Accepted March 26, 2018

DOI: $10.3892 / \mathrm{ol} .2018 .9465$

\begin{abstract}
Uterine natural killer (uNK) cells have been hypothesized to serve a role in controlling trophoblast invasion and proliferation. The aim of the present study was to identify the distribution and number of uNK cells in normal pregnancy (NP), partial mole (PM), complete mole (CM) and invasive mole (IM). uNK cells were detected using dolichos biflorus agglutinin lectin immunohistochemistry in decidual and villous tissues from early NP $(n=15)$, late NP ( $n=15), P M$ $(n=22), C M(n=20)$ and IM $(n=10)$. A scaled eye piece was used for cell counting to obtain semi-quantitative results. It was revealed that uNK cells were mainly located in the uterine deciduas of early NP. As pregnancy progressed, the number of decidual uNK cells significantly decreased. Decidual uNK cells of PM, CM and IM were located near blood vessel endothelial cells. No significant differences were detected with respect to the numbers of decidual $\mathrm{uNK}$ between early NP and PM. However, the number of decidual uNK cells was significantly reduced in CM and IM compared with early NP. The populations of decidual uNK cells were not significantly different between CM and IM. No uNK cells were detected in the villi of PM, CM or IM. The decrease of decidual uNK cells in late NP, CP and IM, compared with early NP, suggested that
\end{abstract}

Correspondence to: Professor Haibin Kuang, Jiangxi Provincial Key Laboratory of Reproductive Physiology and Pathology, Department of Physiology, School of Medicine, Nanchang University, 461 Bayi Road, Nanchang, Jiangxi 330006, P.R. China E-mail: kuanghaibin@ncu.edu.cn

Professor Yan Ling, Department of Obstetrics and Gynecology, Jiangxi Province People's Hospital, 92 Patriotic Road, Nanchang, Jiangxi 330006, P.R. China

E-mail: lingyan1205@163.com

*Contributed equally

Key words: uterine natural killer cells, dolichos biflorus agglutinin lectin, gestational trophoblastic disease, decidua
uNK cells served an important role in controlling trophoblast invasion and proliferation.

\section{Introduction}

Hydatidiform mole is a gestational trophoblastic disease, classified into partial mole (PM) and complete mole (CM), which have the potential to develop into a persistent tumor $(1,2)$. The incidence of hydatidiform mole varies worldwide, at 1/200 livebirths in Southeast Asia, 1/1,000 gestations in Europe and 1/2,000 gestations in the United States $(3,4)$. It is treated by surgical suction evacuation and serial serum human chorionic gonadotropin (hCG) estimations. Spontaneous regression following molar evacuation occurs in $80-90 \%$ cases, and such patients do not require further treatment (5-7). In 10-20\% cases, development into invasive mole and choriocarcinoma occurs. Choriocarcinoma is a malignant trophoblast-cell tumor, characterized by infiltrative and destructive growth, and elevated levels of $\beta$-human chorionic gonadotrophin $(\beta-h C G)(2,5,6,8)$. However, the molecular mechanism of its pathology remains unclear.

Previous findings have demonstrated that uterine natural killer (uNK) cells serve a role in the control of trophoblast invasion, placental development and remodeling of spiral arteries $(7,9,10)$. uNK cells were originally identified by the presence of cytoplasmic granules, thus, they were previously termed granular metrial gland cells $(9,11,12)$. Although uNK cells are granular and express essential proteins required for lysis, they exhibit significantly reduced cytotoxic activity compared with peripheral blood NK cells $(10,13,14)$. Glycoconjugate contents in cytoplasmic granules of uNK cells have been demonstrated to react with Shiff's reagent following periodate treatment, therefore, Periodic acid-Schiff (PAS) staining was established as a method of uNK-cell identification in the mouse and human endometrium $(11,12,15)$. However, the more recently developed dolichos biflorus agglutinin (DBA) lectin staining was demonstrated to be a more sensitive method for the identification and localization of $\mathrm{uNK}$ cells $(16,17)$. DBA lectin can react with glycoconjugates within the granules and at the surface of uNK cells. Furthermore, the DBA lectin method has been used to classify uNK cells into mature and immature uNK cell subtypes (18). 
Prior investigators have demonstrated that uNK cells are associated with gestational trophoblastic diseases (19-22). However, it remains contradictory whether the number of uNK cells is altered in gestational trophoblastic diseases (20-23). In the present study, the distribution and number of uNK cells in normal pregnancy (NP), hydatidiform molar and invasive molar pregnancy were performed using DBA lectin binding activity.

\section{Materials and methods}

Tissue collection. Tissues and clinical information were obtained under the approval of the Ethics Committee of Jiangxi Province People's Hospital (Nanchang, China), and all participants provided informed consent. Tissue samples of normal decidua and placenta of first trimester normal pregnancies $(n=15$; average age of participant, 22.3 years, age range, 19-32 years) were collected from healthy women undergoing suction termination of pregnancy (term, 6-11 weeks) between March 2012 and August 2012, for non-medical reasons. Normal term placenta tissues were collected following uncomplicated pregnancies and vaginal deliveries $(n=15$; average age of participant, 25.7 years; age range, 20-32 years) between March 2012 and November 2012. Paraffin-embedded PM ( $n=22$; average age of participant, 26.1 years; age range, 20-33 years), complete hydatidiform mole ( $n=20$; average age of participant, 29.8 years, age range, 22-33 years) and invasive mole $(n=10$; average age of participant, 33.3 years, age range, 24-36 years) tissues, which had been collected between January 2010 and December 2012, were supplied by the Pathology Department of Jiangxi Province People's Hospital. All the tissue sections were assessed by a gynecological pathologist (Department of Pathology of Jiangxi Province People's Hospital) to confirm diagnosis and ensure suitability for experimental investigation. PM was diagnosed when there was evidence of fetal development, including nucleated red blood cells, or when hydropic change was observed in only a portion of chorionic villi (1). CM was diagnosed by the presence of hydatidiform mole without a fetus, characterized by the transformation of chorionic villi into clusters of vesicles with variable dimensions (1). Invasive mole was diagnosed by the presence of hydatidiform mole, and, microscopically, by the invasion of the myometrium, blood vessels or extrauterine sites by hydropic villi (1). All the patients were physically examined by ultrasound, and patients suffering from chronic disease, uterine abnormalities, infection or genetic abnormalities were excluded.

Mice. Adult Kunming white strain mice $(\mathrm{n}=6 ; 25-30 \mathrm{~g}$; 9 weeks old; Obtained from Nanchang University, Jianxi, China) were housed in a constant photoperiod (14/10 h light/dark cycle) and relative humidity $(55 \pm 10 \%)$ at room temperature with food and water available ad libitum. All the animal procedures were approved by the Institutional Animal Care and Use Committee of Nanchang University (Nanchang, China). Adult female virgin mice were mated with fertile males to induce pregnancy. The identification of a vaginal plug was considered as day 1 of pregnancy. On day 8 of pregnancy, mice were anesthetized with $45 \mathrm{mg} / \mathrm{kg}$ pentobarbital sodium prior to cervical dislocation and uterine collection between 8:00 and 9:00 a.m. The uterine tissues
Table I. Number of uterine natural killer cells in normal, hydatidiform molar and invasive molar pregnancy.

Tissue location

\begin{tabular}{lccc} 
& & & \\
\cline { 3 - 4 } Pregnancy type & Number & Deciduas & Villi \\
\hline Early normal & 15 & $142.3 \pm 10.7$ & $46.8 \pm 5.3^{\mathrm{a}}$ \\
Full term normal & 15 & $2.6 \pm 1.2^{\mathrm{a}}$ & $\mathrm{ND}$ \\
Partial hydatidiform mole & 22 & $156.4 \pm 15.6$ & $\mathrm{ND}$ \\
Complete hydatidiform mole & 20 & $10.3 \pm 3.9^{\mathrm{a}}$ & $\mathrm{ND}$ \\
Invasive hydatidiform mole & 10 & $4.1 \pm 2.2^{\mathrm{a}}$ & $\mathrm{ND}$ \\
\hline
\end{tabular}

The values represent the mean \pm standard error of the mean of the number of positive cells per field in 10 fields. ${ }^{a} \mathrm{P}<0.01 \mathrm{vs}$. deciduas of early normal pregnancy. ND, not detectable.

were frozen at $-80^{\circ} \mathrm{C}$ for later use as positive controls of DBA lectin staining (24).

Histopathological examination. Tissue samples were fixed in $4 \%$ neutral-buffered formalin ( $4 \mathrm{~h}$, room temperature) and embedded in paraffin. The paraffin sections $(5 \mu \mathrm{m})$ were mounted on glass slides coated with poly-l-lysine, then deparaffinized in $100 \%$ xylene, rehydrated in graded ethanol solutions $(100,95,80$ and $70 \%)$, and stained with hematoxylin and eosin. The pathological diagnosis of partial, complete molar and invasive molar pregnancies was based on the aforementioned standard histopathological criteria (1), and performed by a gynecological pathologist. The hydatidiform mole and invasive mole samples were further stained with anti-human cytokeratin (dilution, 1:200; sc-70906; Santa Cruz Biotechnology, Santa Cruz, USA) to identify the presence and position of trophoblast cells overnight at $4^{\circ} \mathrm{C}$. The sections were incubated with a horseradish peroxidase-conjugated secondary antibody (dilution, 1:200; ZB-2306) for $50 \mathrm{~min}$ at $37^{\circ} \mathrm{C}$ followed by $0.05 \%$ fresh diaminobenzidine solution for 4 min, together with counter-staining with 5\% Harris' hematoxylin solution for $5 \mathrm{sec}$ at room temperature (all Zhongshan Golden Bridge Biotechnology Co., Ltd., Beijing, China). Brown-yellow staining in the cytoplasm was observed to indicate a positive signal in a conventional light microscope (magnification, x200; Olympus Corporation, Tokyo, Japan).

DBA lectin immunohistochemistry. DBA lectin staining was performed as previously described (24). Endogenous peroxidase activity was blocked by incubating the sections in $3 \% \mathrm{H}_{2} \mathrm{O}_{2}$ for $10 \mathrm{~min}$ at room temperature. Non-specific antibody binding was blocked in $5 \%$ bovine serum albumin (Zhongshan Golden Bridge Biotechnology Co., Ltd.) for $60 \mathrm{~min}$ at room temperature. The sections were then incubated in biotinylated-DBA lectin (dilution, 1:1,500; Sigma-Aldrich; Merck KGaA, Darmstadt, Germany) overnight at $4^{\circ} \mathrm{C}$. Following washing in PBS, the sections were incubated with streptavidin-peroxidase for another $60 \mathrm{~min}$ at $37^{\circ} \mathrm{C}$. Positive signals were detected with $0.05 \%$ 3,3'-diaminobenzidine solution and counter-stained with 5\% Harris' hematoxylin solution (all Zhongshan Golden Bridge Biotechnology Co., 

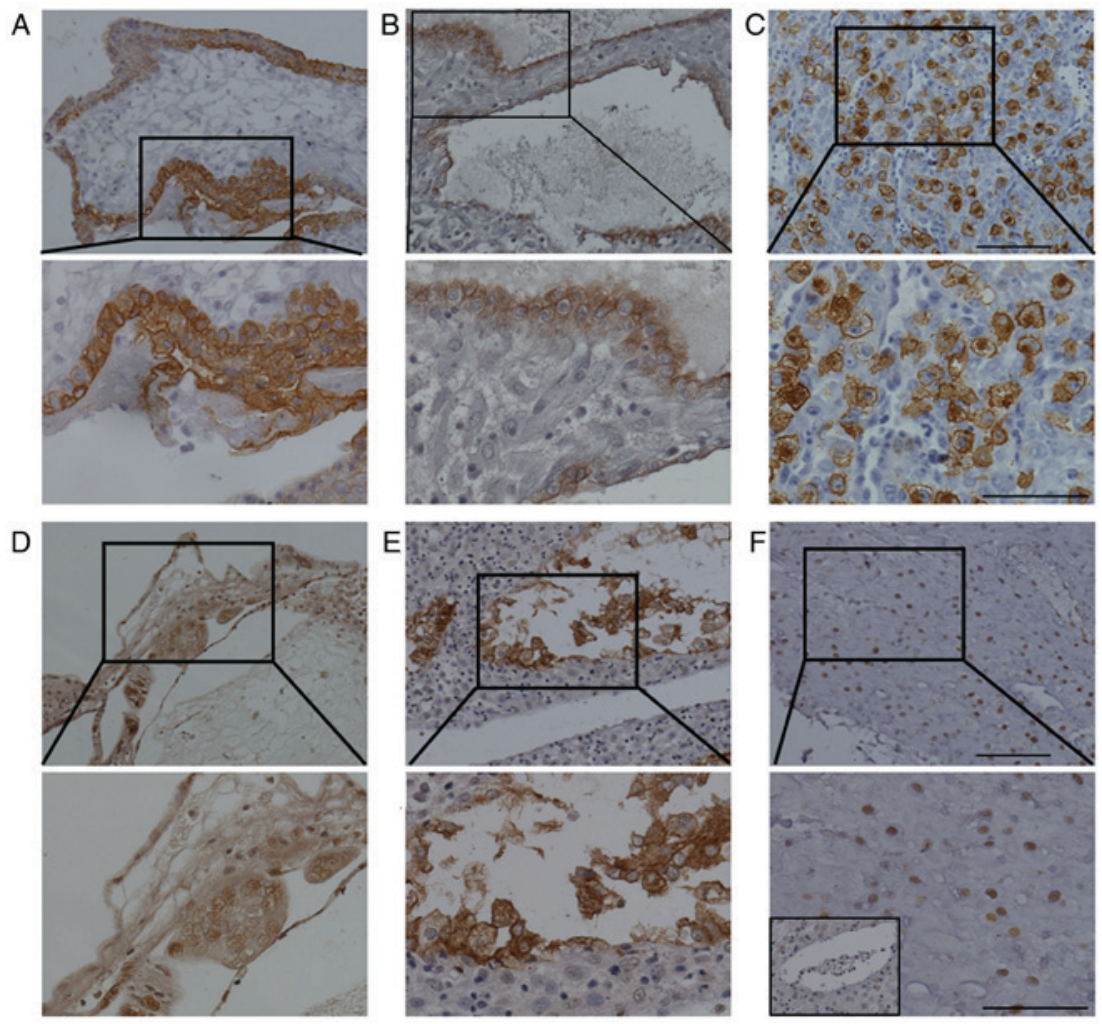

Figure 1. Distribution of uNK cells at the maternal-fetal interface in the first trimester normal pregnancy. Trophoblast cell-identifying cytokeratin staining of (A) villous and (B) decidual tissue. (C) Mouse uterus tissue at day 8 of normal pregnancy, used as a positive control. Brown-yellow staining indicates positive DBA lectin staining of uNK cells. (D) Photomicrograph of DBA lectin-stained villous sections from the first trimester of normal pregnancy. (E-F) Photomicrographs of DBA lectin-stained decidual sections from the first trimester of normal pregnancy indicating (E) large mature uNK cells and (F) smaller immature NK cells. Each tissue is represented at magnification, x200 (above) and x400 (below). Inset of F (below) shows immunostaining of a negative control-stained section (primary antibody was replaced by $0.1 \mathrm{M} \mathrm{N}$-acetyl-D-galactosamine). uNK, uterine natural killer; DBA, dolichos biflorus agglutinin. Scale bar, $50 \mu \mathrm{m}$.

Ltd.) $2 \mathrm{~min}$ at room temperature. The addition of $0.1 \mathrm{M}$ $\mathrm{N}$-acetyl-D-galactosamine (Sigma-Aldrich; Merck KGaA) to the DBA lectin incubation provided a negative control.

Microscopic evaluation. Microscopic evaluation was performed blindly by two independent pathologists using a light microscope. The number of cells positive for DBA lectin staining was counted in 10 non-overlapping fields at magnification, $\mathrm{x} 400$. The procedure was repeated in 2 specimens from each subject. The mean number of cells was calculated per patient, then per patient group.

Statistics analysis. The data are presented as the mean \pm standard error of the mean. The Mann-Whitney U test was used to determine statistically significant differences. $\mathrm{P}<0.05$ was considered to indicate a statistically significant difference. All statistical analyses were performed using SPSS 13.0 (SPSS, Inc., Chicago, IL, USA).

\section{Results}

Distribution and number of $u N K$ cells in NP. Firstly, the identity of trophoblastic cells in the villous (Fig. 1A) and decidual tissue (Fig. 1B) was confirmed by staining for cytokeratin. Mouse uterine tissues from day 8 of NP were stained with DBA lectin as a positive control (Fig. 1C). The results demonstrated that uNK cells were located at the mesometrial pole of implantation sites.
The cells were large in size and exhibited heavy cytoplasmic granules (Fig. 1C). In villi of early NP, a number of small uNK cells were distributed in the villous stroma (Fig. 1D). In the deciduas of early NP, DBA lectin staining demonstrated that 2 forms of uNK cells were located in different regions of the decidual tissues (Fig. 1E). Mature uNK cells were large in size and exhibited strong brown staining of the cellular cytoplasm. The membranes were mainly distributed near endothelial cells of decidual blood vessels (Fig. 1E). The smaller immature uNK cells exhibited weak brown staining of the nucleus and were scattered among decidual cells (Fig. 1F). The number of uNK cells in the villi was significantly lower than that in the decidual samples of early pregnancy ( $46.8 \pm 5.3$ vs. $142.3 \pm 10.7$; Table I). However, at full term NP, DBA lectin staining was almost negligible in decidual and placental chorionic villous tissue (Fig. 2; Table I).

Distribution and number of uNK cells in PM. H\&E staining for deciduas (Fig. 3A) and villi (Fig. 3B) of PM was observed to identify the mole histologically. The identity of trophoblastic cells in the decidua (Fig. 3C) and villi (Fig. 3D) of PM was confirmed by staining for cytokeratin. DBA lectin staining demonstrated that decidual uNK cells were mainly located near blood vessel endothelial cells in PM (Fig. 3E). No significant difference was detected between the number of decidual uNK cells in PM and early NP $(156.4 \pm 15.6$ vs. $142.3 \pm 10.7$; $\mathrm{P}>0.05)$. In addition, DBA lectin staining was not detected in the villi of PM (Fig. 3F). 

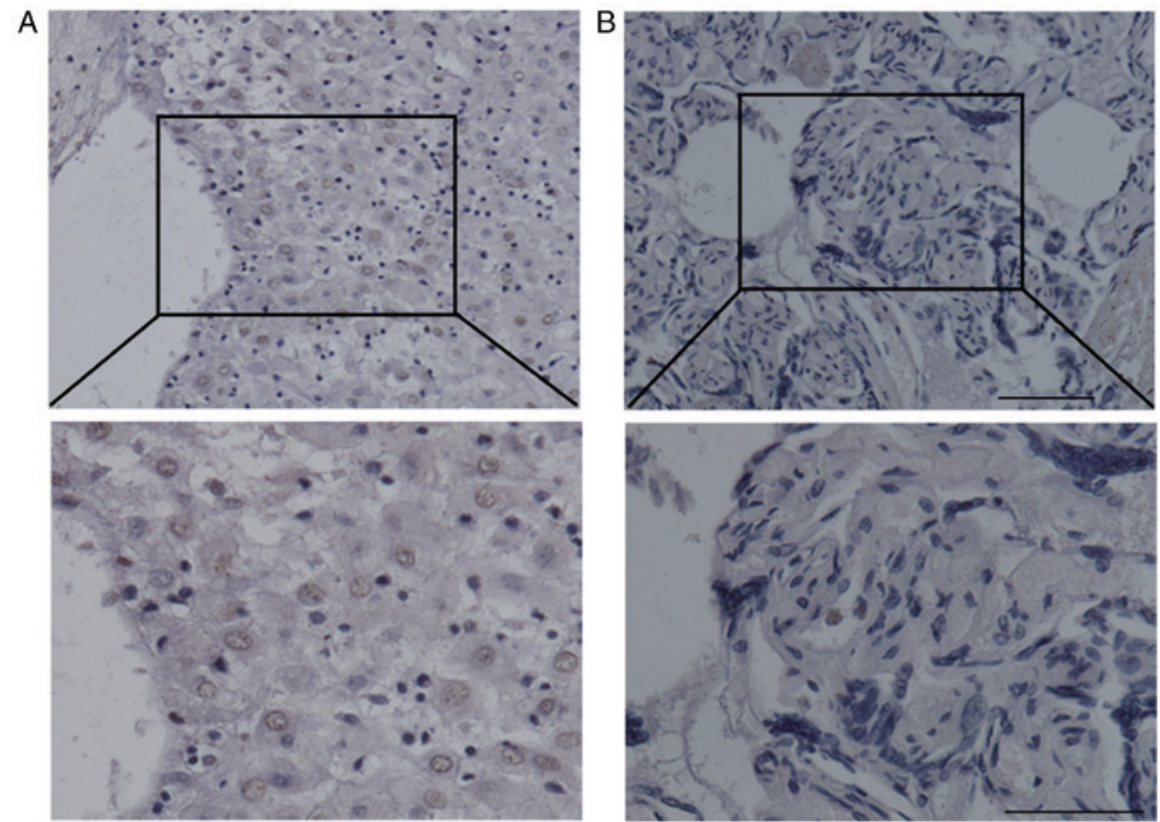

Figure 2. Distribution of uNK cells at the normal maternal-fetal interface in term pregnancy. (A) Photomicrograph of DBA lectin-stained decidual tissue section of a normal term pregnancy. (B) Photomicrograph of DBA lectin-stained villous section from normal term pregnancy. Each tissue is represented at magnification, x200 (above) and x400 (below). uNK, uterine natural killer; DBA, dolichos biflorus agglutinin. Scale bar, $50 \mu \mathrm{m}$.
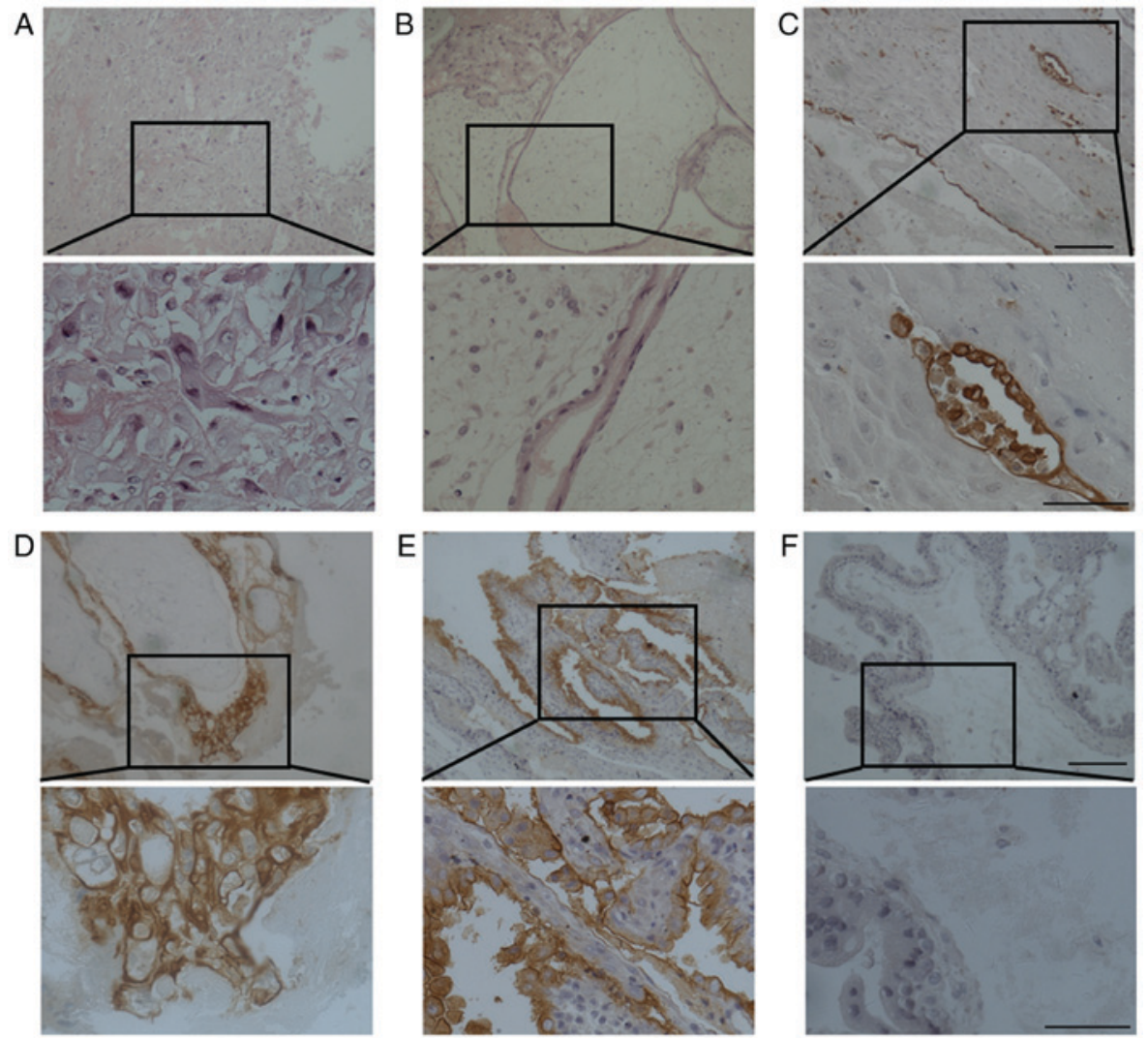

Figure 3. Distribution of uNK cells in partial hydatidiform mole. Hematoxylin and eosin staining of (A) decidual and (B) villous tissue of partial hydatidiform mole. Cytokeratin staining of (C) decidual and (D) villous tissue of hydatidiform mole to identify trophoblast cells. Brown staining indicates cytokeratin protein expression. Photomicrographs of DBA lectin staining of (E) decidual and (F) villous tissue of partial hydatidiform mole. Each tissue is represented at magnification, x200 (above) and x400 (below). uNK, uterine natural killer; DBA, dolichos biflorus agglutinin. Scale bar, $50 \mu \mathrm{m}$.

Distribution and number of uNK cells in CM. H\&E staining for deciduas (Fig. 4A) and villi (Fig. 4B) of CM was observed to identify the mole histologically. The identity of trophoblastic cells in the decidua (Fig. 4C) and villi (Fig. 4D) of CM was also confirmed by staining for cytokeratin. In CM, decidual uNK cells were also identified near blood vessel endothelial cells 

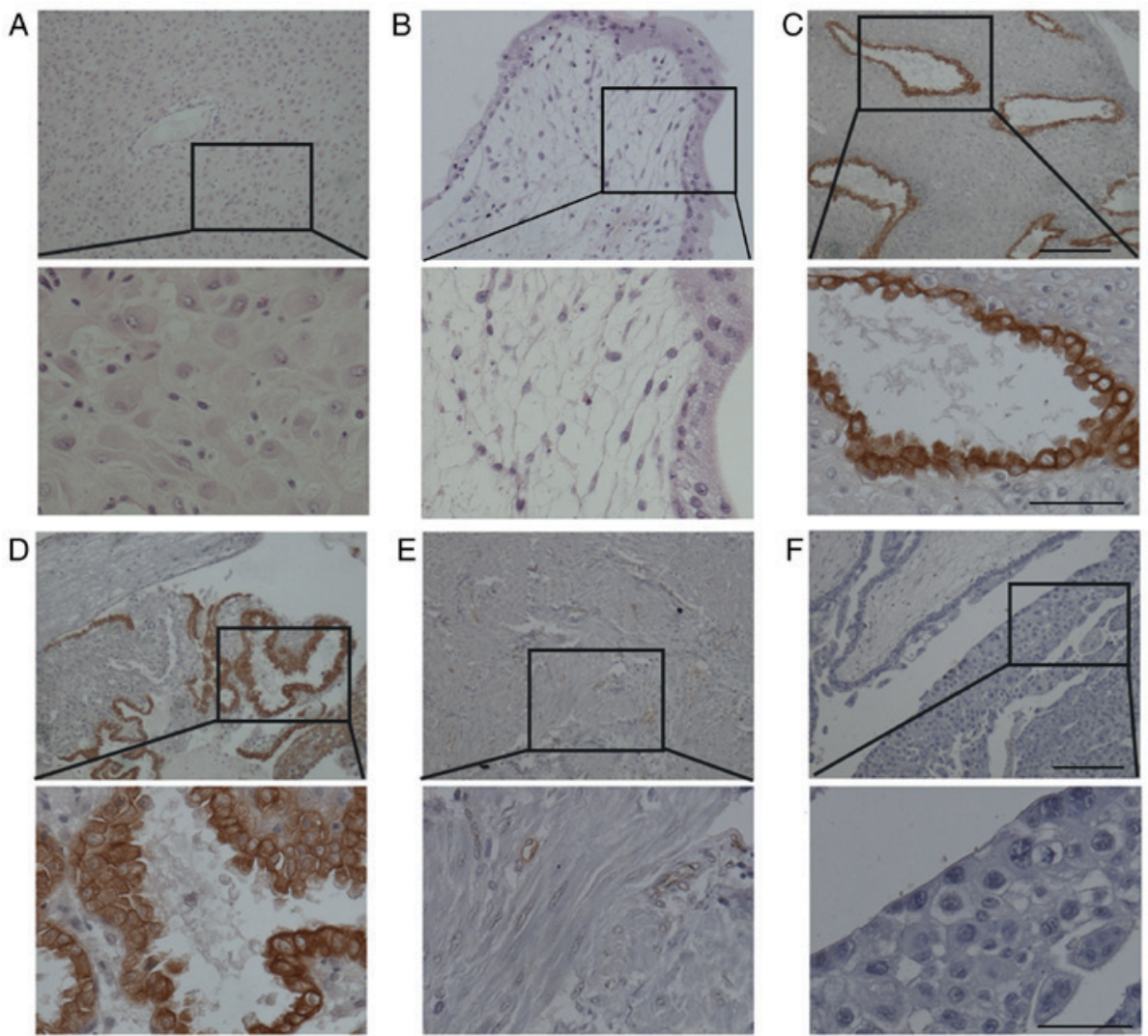

Figure 4. Distribution of uNK cells in complete hydatidiform mole. Hematoxylin and eosin staining of (A) decidual and (B) villous tissue of complete hydatidiform mole. Cytokeratin staining of (C) decidual and (D) villous tissue to identify trophoblast cell. Brown staining indicates cytokeratin protein expression. Photomicrographs of DBA lectin staining of (E) decidual and (F) villous tissue of complete hydatidiform mole. Each tissue is represented at magnification, x200 (above) and x400 (below). uNK, uterine natural killer; DBA, dolichos biflorus agglutinin. Scale bar, $50 \mu \mathrm{m}$.

(Fig. 4E). However, the number of decidual uNK cells was significantly decreased in $\mathrm{CM}(10.3 \pm 3.9 ; \mathrm{P}<0.01)$ compared with early NP $(142.3 \pm 10.7$, Table I). In addition, DBA lectin staining was also not detected in the villi of CM (Fig. 4F).

Distribution and number of uNK cells in IM. H\&E staining for deciduas (Fig. 5A) and villi (Fig. 5B) of IM was observed to identify the mole histologically. The identity of trophoblastic cells in the decidua (Fig. 5C) and villi (Fig. 5D) of IM was also confirmed by staining for cytokeratin. In IM, decidual uNK cells were also identified near blood vessel endothelial cells (Fig. 5E). However, the number of decidual uNK cells was significantly decreased in IM $(4.1 \pm 2.2 ; \mathrm{P}<0.01)$ compared with early NP (142.3 \pm 10.7 , Table I). No significant difference was identified with regard to the number of decidual uNK cells in $\mathrm{CM}$ and IM (10.3 \pm 3.9 vs. $4.1 \pm 2.2 ; \mathrm{P}>0.05)$. In addition, DBA lectin staining was also not detected in the villi of IM (Fig. 5F).

\section{Discussion}

The present study revealed that uNK cells were mainly located in the uterine decidual tissue of early NP. With progression of pregnancy, the number of uNK cells significantly decreased. In the deciduas of hydatidiform mole (including PM, CM and invasive mole), the DBA lectin staining demonstrated that uNK cells were mainly distributed near blood vessel endothelial cells. No significant difference was identified between the number of decidual uNK cells in partial hydatidiform mole and early NP.
However, the number of decidual uNK cells was significantly decreased in complete and invasive mole compared with early $\mathrm{NP}$, suggesting that $\mathrm{CM}$ has a high risk of developing malignant trophoblast disease compared with PM. Bagshawe et al (5) demonstrated that the risk of developing a tumor was $15 \%$ in $\mathrm{CM}$ and $0.5 \%$ in PM.

A previous study demonstrated that the number of uNK cells is dynamic within the menstrual cycle (25). uNK cells have been reported to be absent in the proliferative endometrium, and the cell number has been reported to increase in the mid- to late-luteal phase of the menstrual cycle and in early pregnancy $(9,25)$. The present study demonstrated that uNK cells were highly abundant and moderately scattered among uterine decidual cells in the first trimester of pregnancy, which is in accordance with a previous study (23). It was also identified that a proportion of decidual uNK cells were distributed near blood vessel endothelial cells in early pregnancy. It has been previously suggested that blood vessel-adjacent uNK cells may be able to secrete a series of cytokines, including interferon $\gamma$ (IFN- $\gamma$ ), angiopoietin (Ang)1, placental growth factor, transforming growth factor- $\beta 1$ (TGF- $\beta 1$ ), and vascular endothelial growth factor (VEGF)C, which are critical in angiogenesis and placental development $(26,27)$. Furthermore, it has been indicated that mice with uNK-cell or IFN- $\gamma$ signaling deficiencies (recombination activating gene $2^{-/-}$or IFN- $\gamma^{-/-}$mice, respectively) exhibit decidual artery remodeling failure and have implantation site abnormalities $(28,29)$. 

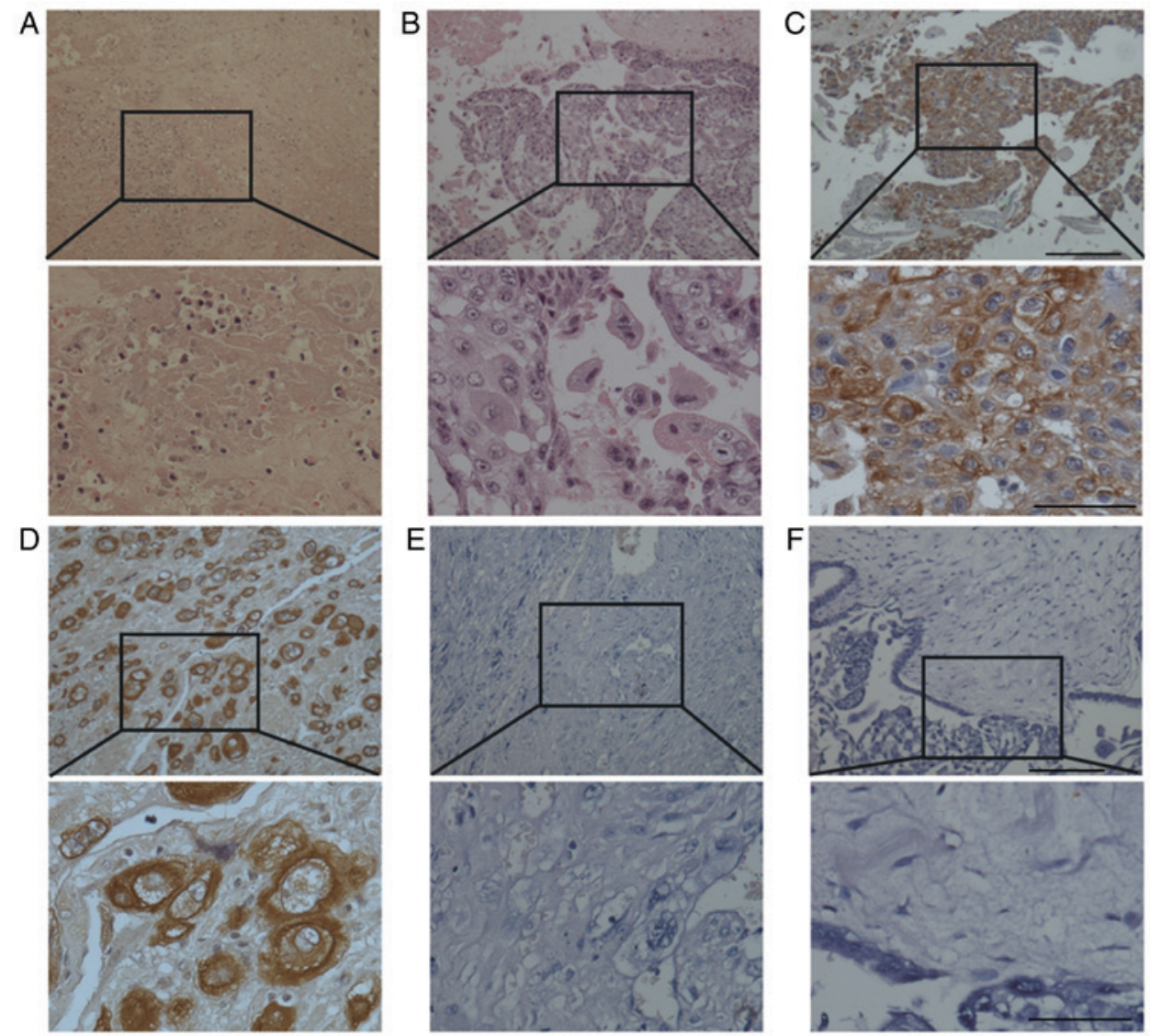

Figure 5. Distribution of uNK cells in invasive hydatidiform mole. Hematoxylin and eosin staining of (A) decidual and (B) and villous tissue of invasive hydatidiform mole. Cytokeratin staining of (C) decidual and (D) villous tissue to identify trophoblast cell. Brown staining indicates cytokeratin protein expression Photomicrographs of DBA lectin staining of (E) decidual and (F) villous tissue of complete hydatidiform mole. Each tissue is represented at magnification, x200 (above) and x400 (below). uNK, uterine natural killer; DBA, dolichos biflorus agglutinin. Scale bar, $50 \mu \mathrm{m}$.

Contradictory data exist with respect to uNK cell number in the third trimester of NP $(9,20,23)$. A number of studies reported that uNK cells expressing cluster of differentiation (CD) $56^{+}$(a key marker for human uNK cells) were substantial in number in decidual tissue in the third trimester of NP $(20,23)$. Williams et al (23) demonstrated that substantial numbers of $\mathrm{CD}^{+} 6^{+} \mathrm{uNK}$ cells remain in decidua at full term pregnancy. Other studies suggested that uNK cells were virtually absent at full term NP (20-22). In the present study, almost negligible DBA lectin staining was evident in the decidual and villous tissue at full term. These conflicting results may be due to variability in samples and research techniques.

Cytogenetic studies demonstrated that the karyotype of partial molar pregnancy is $69, \mathrm{XXY}$ or $69, \mathrm{XXX}$, resulting from the fertilization of an ovum by 2 sperm (1). Consequently, PM can be defined as a partial allograft, as can NP. However, CM is defined as a complete allograft seeing as all chromosomes are of paternal origin $(2,3)$. An immunological response against foreign paternal antigens would be predicted, therefore, researchers have explored immune cell profiling in NP and molar pregnancy, including that of macrophages, natural killer (NK) cells and T cells. Nagymanyoki et al (22) revealed a significant increase in cytotoxic T-cell and granzyme $\mathrm{B}(\mathrm{GrB})^{+} \mathrm{NK}$-cell numbers at the implantation site of CM by immunostaining of CD8, $\mathrm{GrB}$ and forkhead box P3. However, Knoeller et al (21) demonstrated that the number of CD8 T cells, CD3 T cells and mast cells significantly increased, and $\mathrm{CD}^{+} 6^{+} \mathrm{NK}$ cell number decreased, in choriocarcinoma and hydatidiform mole compared with NP, using antibodies against CD8, CD3, CD56, CD68 and mast cell tryptase. In the present study, it was demonstrated that the number of decidual uNK cells was significantly reduced in CM and invasive mole compared with early NP. This suggests that uNK cells may serve a pivotal role in the control of trophoblast invasion and proliferation. The likely mechanisms of uNK cell regulation of trophoblast invasion are cytokine and growth factor secretion, including IFN- $\gamma$, transforming growth factor- $\beta 1$, interleukin-1 $\beta$, TNF- $\alpha$, VEGFC, placental growth factor, Ang-2, leukemia inhibitory factor and colony stimulating factor-1 $(30,31)$.

In summary, the present study demonstrates that the number of decidual uNK cells was significantly reduced in full term NP, CM and invasive mole compared with early NP. This suggests that uNK cells may serve an important role in the regulation of trophoblast invasion and proliferation. However, further research is required to establish the role of uNK cells in the diagnosis and treatment of gestational trophoblastic disease.

\section{Acknowledgements}

The authors would like to thank Dr Min Jiang at Jiangxi Province People's Hospital for proofreading the manuscript. 


\section{Funding}

The present study was supported by the National Natural Science Foundation of China (grant no. 81671486), and the 555 project of Jiangxi Province Gan Po Excellence and Post-graduate Innovation Project of Nanchang University (grant nos. cx2015176 and cx2016355).

\section{Availability of data and materials}

The datasets used and/or analyzed during the current study are available from the corresponding author on reasonable request.

\section{Authors' contributions}

TZh, XX and HK conceived and designed the experiment. TZh, XX, TZo and XY carried out all the experiments. YL was responsible for collection of the samples. TZh and YL analyzed the data. TZh, XX and HK drafted the paper. All authors revised the paper, read and approved the final manuscript.

\section{Ethics approval and consent to participate}

Patient tissues and clinical information were obtained under the approval of Ethical Committee of Jiangxi Province People's Hospital, and all participants provided informed consent. All animal procedures were approved by the Institutional Animal Care and Use Committee of Nanchang University.

\section{Patient consent for publication}

Written informed consent was obtained from each patient for the publication of their data.

\section{Competing interests}

The authors declare that they have no competing interests.

\section{References}

1. Cheung AN: Pathology of gestational trophoblastic diseases Best Pract Res Clin Obstet Gynaecol 17: 849-868, 2003.

2. Monchek R and Wiedaseck S: Gestational trophoblastic disease: An overview. J Midwifery Womens Health 57: 255-259, 2012.

3. Seckl MJ, Sebire NJ and Berkowitz RS: Gestational trophoblastic disease. Lancet 376: 717-729, 2010.

4. Tse KY, Chan KKL, Tam KF and Ngan HYS: Gestational trophoblastic disease. Obstet Gynaecol Reprod Med 19: 89-97, 2009.

5. Bagshawe KD, Lawler SD, Paradinas FJ Dent J, Brown P and Boxer GM: Gestational trophoblastic tumours following initial diagnosis of partial hydatidiform mole. Lancet 335: 1074-1076, 1990.

6. Berkowitz RS and Goldstein DP: Chorionic tumors. N Engl J Med 335: 1740-1748, 1996.

7. Sebire NJ, Fisher RA and Rees HC: Histopathological diagnosis of partial and complete hydatidiform mole in the first trimester of pregnancy. Pediatr Dev Pathol 6: 69-77, 2003.

8. Turgut EN, Celik E, Celik S, Arikan DC, Altuntas H,Leblebici C, Purisa S and Dansuk R: Could serum $\beta$-hCG levels and gestational age be the indicative factors for the prediction of the degree of trophoblastic invasion into tubal wall in unruptured ampullary pregnancies? Arch Gynecol Obstet 287: 323-328, 2013.

9. Bulmer JN and Lash GE: Human uterine natural killer cells: A reappraisal. Mol Immunol 42: 511-521, 2005.

10. Santoni A, Carlino C and Gismondi A: Uterine NK cell development, migration and function. Reprod Biomed Online 16: 202-210, 2008
11. Stewart I and Peel S: Granulated metrial gland cells at implantation sites of the pregnant mouse uterus. Anat Embryol (Berl) 160: 227-238, 1980.

12. Bulmer D: Further studies on the granulated metrial gland cells of the pregnant rat. J Anat 103: 479-489, 1968.

13. Croy BA, He H, Esadeg S, Wei Q, McCartney D, Zhang J, Borzychowski A, Ashkar AA, Black GP, Evans SS, et al: Uterine natural killer cells: Insights into their cellular and molecular biology from mouse modelling. Reproduction 126: 149-160, 2003.

14. van den Heuvel MJ, Xie X, Tayade C, Peralta C, Fang Y, Leonard S, Paffaro VA Jr, Sheikhi AK, Murrant C and Croy BA: A review of trafficking and activation of uterine natural killer cells. Am J Reprod Immunol 54: 322-331, 2005.

15. Hamperl H and Hellweg G: Granular endometrial stroma cells. Obstet Gynecol 11: 379-387, 1958.

16. Stewart IJ and Webster AJ: Lectin histochemical studies of mouse granulated metrial gland cells. Histochem J 29: 885-892, 1997.

17. Stewart J, Bebington CR and Mukhtar DD: Lectin binding characteristics of mouse placental cells. J Anat 196: 371-378, 2000.

18. Paffaro VA Jr, Bizinotto MC, Joazeiro PP and Yamada AT: Subset classification of mouse uterine natural killer cells by DBA lectin reactivity. Placenta 24: 479-488, 2003.

19. El Costa H, Tabiasco J, Berrebi A, Parant O, Aguerre-Girr M, Piccinni MP and Le Bouteiller P: Effector functions of human decidual NK cells in healthy early pregnancy are dependent on the specific engagement of natural cytotoxicity receptors. J Reprod Immunol 82: 142-147, 2009.

20. Haller H, Radillo O, Rukavina D, Tedesco F, Candussi G, Petrović O and Randić L: An immunohistochemical study of leucocytes in human endometrium, first and third trimester basal decidua. J Reprod Immunol 23: 41-49, 1993.

21. Knoeller S, Lim E, Aleta L, Hertwig K, Dudenhausen JW and Arck PC: Distribution of immunocompetent cells in decidua of controlled and uncontrolled (choriocarcinoma/hydatidiform mole) trophoblast invasion. Am J Reprod Immunol 50: 41-47, 2003.

22. Nagymanyoki Z, Callahan MJ, Parast MM, Fulop V, Mok SC and Berkowitz RS: Immune cell profiling in normal pregnancy, partial and complete molar pregnancy. Gynecol Oncol 107: 292-297, 2007.

23. Williams PJ, Searle RF, Robson SC, Innes BA and Bulmer JN: Decidual leucocyte populations in early to late gestation normal human pregnancy. J Reprod Immunol 82: 24-31, 2009.

24. Kuang H, Peng H, Xu H, Zhang B, Peng J and Tan Y: Hormonal regulation of uterine natural killer cells in mouse preimplantation uterus. J Mol Histol 41: 1-7, 2010.

25. Igarashi T, Konno R, Okamoto S, Moriya T, Satoh S and Yajima A: Involvement of granule-mediated apoptosis in the cyclic changes of the normal human endometrium. Tohoku J Exp Med 193: 13-25, 2001.

26. Lash GE, Schiessl B, Kirkley M, Innes BA, Cooper A, Searle RF, Robson SC and Bulmer JN: Expression of angiogenic growth factors by uterine natural killer cells during early pregnancy. J Leukoc Biol 80: 572-580, 2006.

27. Lobo SC, Huang ST, Germeyer A, Dosiou C, Vo KC, Tulac S, Nayak NR and Giudice LC: The immune environment in human endometrium during the window of implantation. Am J Reprod Immunol 52: 244-251, 2004.

28. Ashkar AA, Di Santo JP and Croy BA: Interferon gamma contributes to initiation of uterine vascular modification, decidual integrity, and uterine natural killer cell maturation during normal murine pregnancy. J Exp Med 192: 259-270, 2000.

29. Acar N, Ustunel I and Demir R: Uterine natural killer (uNK) cells and their missions during pregnancy: A review. Acta Histochemica 113: 82-91, 2011.

30. Li XF, Charnock-Jones DS, Zhang E, Hiby S, Malik S, Day K, Licence D, Bowen JM, Gardner L, King A, et al: Angiogenic growth factor messenger ribonucleic acids in uterine natural killer cells. J Clin Endocrinol Metab 86: 1823-1834, 2001.

31. Jokhi PP, King A and Loke YW: Cytokine production and cytokine receptor expression by cells of the human first trimester placental-uterine interface. Cytokine 9: 126-137, 1997.

This work is licensed under a Creative Commons Attribution-NonCommercial-NoDerivatives 4.0 International (CC BY-NC-ND 4.0) License. 